\title{
Tretogonia Melichar (Hemiptera: Cicadellidae: Proconiini): two new species from South Brazil and a redescription of T. dentalis Emmrich, 1988
}

\author{
Gabriel MEJDALANI ${ }^{1}$, Alexandre C. DOMAHOVSKI ${ }^{2, *}$, \\ Diana I. RENDÓN-MERA ${ }^{3} \&$ Rodney R. CAVICHIOLI ${ }^{4}$ \\ ${ }^{1}$ Departamento de Entomologia, Museu Nacional, Universidade Federal do Rio de Janeiro, \\ Quinta da Boa Vista, São Cristóvão, 20940-040, Rio de Janeiro, RJ, Brazil. \\ ${ }^{2,3,4}$ Departamento de Zoologia, Setor de Ciências Biológicas, Universidade Federal do Paraná, \\ Caixa Postal 19020, 81531-980, Curitiba, PR, Brazil. \\ ${ }^{*}$ Corresponding author: domahovskiac@yahoo.com.br \\ ${ }^{1}$ Email: mejdalan@acd.ufrj.br \\ ${ }^{3}$ Email: direndonm@gmail.com \\ ${ }^{4}$ Email: cavich@ufpr.br

\footnotetext{
${ }^{1}$ urn:1sid:zoobank.org:author:DE1C60FA-FB28-4F73-B316-18E901D5783D

${ }^{2}$ urn:1sid:zoobank.org:author:0B988BD5-599B-42CE-ADCB-50FC813E104E

${ }^{3}$ urn:lsid:zoobank.org:author:A4349B08-D9E1-42D7-AB02-507A6DC1D051

${ }^{4}$ urn:1sid:zoobank.org:author:58DD5B1D-2A8E-4504-B427-6A6E18E87498
}

\begin{abstract}
Two new Brazilian sharpshooter species of the genus Tretogonia Melichar, 1926 are described and illustrated: Tretogonia diminuta sp. nov. and T. elegantula sp. nov., both from the State of Paraná. A redescription of T. dentalis Emmrich, 1988 is provided based on a male from the State of Mato Grosso do Sul. This is the first Brazilian record of T. dentalis, a species originally described from Paraguay. Photographs and line drawings are provided for the three species, as well as notes on the taxonomy and biology of the genus.
\end{abstract}

Keywords. Auchenorrhyncha, sharpshooter leafhoppers, taxonomy, morphology.

Mejdalani G., Domahovski A.C., Rendón-Mera D.I. \& Cavichioli R.R. 2019. Tretogonia Melichar (Hemiptera: Cicadellidae: Proconiini): two new species from South Brazil and a redescription of T. dentalis Emmrich, 1988. European Journal of Taxonomy 513: 1-14. https://doi.org/10.5852/ejt.2019.513

\section{Introduction}

The subfamily Cicadellinae is composed of leafhoppers that feed on the xylem of vascular plants and includes some vectors of xylem-borne phytopathogenic bacteria; the copious amounts of watery excreta forcibly excreted by these insects during feeding has given rise to their common name of sharpshooters (Nielson \& Knight 2000; Redak et al. 2004; Carvalho \& Mejdalani 2006). Currently, the subfamily includes only two tribes (Young 1968), the cosmopolitan Cicadellini and the New World Proconiini. 
The latter, which includes the genus treated herein, is especially diverse in the Neotropical region. The Proconiini can be distinguished from the Cicadellini by the following features (Young 1968): (1) antennal ledges protuberant in dorsal view, (2) hind legs at rest position not attaining the lateral lobes of the pronotum (exception: Splonia Signoret, 1891) and (3) male pygofer and subgenital plates with dispersed microsetae. The tribe currently comprises 60 genera and over 400 species. With adults usually varying in length from 10 to $22 \mathrm{~mm}$ (Evans 1947), the Proconiini are among the largest leafhoppers. Furthermore, their morphology shows quite peculiar and curious features, such as the elongate head process of Raphirhinus Laporte, 1832, the keeled pronotum of Proconia Peletier \& Serville, 1825 and the greatly flattened and expanded anterior tibiae of Peltocheirus Walker, 1858 (see digital images of these remarkable genera in Wilson et al. 2009).

Tretogonia is a Neotropical genus distributed from Panama to Argentina (Young 1968; Wilson et al. 2009). It was erected by Melichar (1926), who designated Tettigonia pruinosa Walker, 1851 as the type species; in addition, he included Tettigonia striata Walker, 1851 in Tretogonia and described five new species: T. callifera, T. conspicua, T. cribrata, T. notatifrons and T. punctatissima. Subsequently, Oman (1949) transferred T. striata to Cuerna Melichar, 1925 and Metcalf (1965) renamed T. pruinosa as T. walkeri because the original name was preoccupied. However, Young (1968) synonymized T. walkeri with $T$. notatifrons. The latter author also transferred four previously described species to Tretogonia (Amblydisca cinerea Osborn, 1926, Oncometopia tomentosa Distant, 1908, Tettigonia albicans Walker, 1858 and Tettigonia lateritia Taschenberg, 1884) and described two new species (Tretogonia bergi and T. costalimai). Emmrich (1988) described an additional new species (T. dentalis). Currently, Tretogonia comprises 13 valid species (McKamey 2007). Tretogonia albicans, T. conspicua and T. lateritia are known only from female specimens (Young 1968).

Eight of the 13 previously known Tretogonia species have been recorded from Brazil (Cavichioli \& Zanol 1991; Takiya et al. 2018). The biology of the known species of this genus is poorly known. However, Mejdalani \& Emmrich (1998) reported the occurrence of specimens of T. cribrata on plants from freshwater habitats, such as Eleocharis sellowiana Kunth. and Rhynchospora sp. (both Cyperaceae) from a littoral sand dune marsh and Typha dominguensis Pers. (Typhaceae) from a dam located in an area of Atlantic Forest (about $1200 \mathrm{~m}$ a.s.1.). Light traps are the most effective method for collecting specimens of Tretogonia.

In the present study, we describe two new species of Tretogonia from South Brazil, T. diminuta sp. nov. and T. elegantula sp. nov., both collected in the State of Paraná. In addition, we provide a redescription of T. dentalis based on a male from the State of Mato Grosso do Sul. This is the first Brazilian record of T. dentalis, which was originally described from Paraguay (Emmrich 1988). For the three species, we present detailed descriptions, photographs, line drawings of the male terminalia and comparative notes.

\section{Material and methods}

The material examined here is deposited at the Coleção Entomológica Padre Jesus Santiago Moure, Departamento de Zoologia, Setor de Ciências Biológicas, Universidade Federal do Paraná, Curitiba, Brazil (DZUP) and the Departamento de Entomologia, Museu Nacional, Universidade Federal do Rio de Janeiro, Brazil (MNRJ). Due to the tragic fire at the Museu Nacional, which occurred on the night of September $2^{\text {nd }}, 2018$, the new insect collection is temporarily housed in the Departamento de Vertebrados of that institution.

Techniques for preparation of male and female terminalia structures follow Oman (1949) with modifications by Cavichioli \& Takiya (2012). For dissection of male and female terminalia, we follow Oman (1949) and Mejdalani (1998), respectively. Terminalia were analyzed and photographed in glycerin and subsequently stored in microvials attached to the corresponding specimen pin. 
Descriptive terminology follows mainly Young $(1968,1977)$, except for the facial areas of the head (Hamilton 1981; Mejdalani 1993, 1998) and the female terminalia (Nielson 1965; Hill 1970). The use of the term gonoplac (= third ovipositor valvula) follows Mejdalani (1998).

Label data are quoted exactly with a virgule (/) separating lines on the labels and with explanatory notes in square brackets.

\section{Results}

Family Cicadellidae Latreille, 1825

Subfamily Cicadellinae Latreille, 1825

Tribe Proconiini Stål, 1869

Genus Tretogonia Melichar, 1926

Tretogonia Melichar, 1926: 273 (type species: Tettigonia pruinosa Walker, 1851, preoccupied (= Tretogonia notatifrons Melichar, 1926), by original designation).

\section{Remarks}

According to Young (1968), Tretogonia belongs to the group of genera in which the hind leg meron is exposed when the forewings are at rest position. It can be recognized by the following combination of characters (characters (1) and (4) are proposed here for the first time as taxonomically useful): (1) antennal ledge with distinct dorsal and ventral carinae, in frontal and lateral views, (2) pronotum and forewings conspicuously pitted, each pit with small seta, (3) posterior margin of pronotum rounded and extending to scutoscutellar suture, (4) forewing brachial cell distinctly narrowed basally and (5) general coloration brown. In species of Tretogonia, the body is usually densely covered by brochosomes. The two new Brazilian species described here show the above-mentioned diagnostic features of Tretogonia. This genus is apparently monophyletic, as indicated by the morphological phylogenetic analysis of the Proconiini conducted by Mejdalani (2000). Synapomorphies of Tretogonia include the pronotum strongly produced posteriorly, the conspicuous pronotal and forewing pits, and the narrowed forewing brachial cell (Mejdalani 2000).

The following species are currently recognized in this genus (distribution based on Young 1968, Cavichioli \& Zanol 1991, Freytag \& Sharkey 2002, McKamey 2007, Wilson et al. 2009, Dellapé 2016 and Takiya et al. 2018; an asterisk indicates species known only from females):

T. albicans (Walker, 1858)*. Brazil.

T. bergi Young, 1968. Argentina, Brazil, Paraguay, Uruguay.

T. callifera Melichar, 1926. Bolivia, Brazil, French Guiana, Peru, Suriname.

T. cinerea (Osborn, 1926). Bolivia, Brazil.

T. conspersa Schmidt, 1928. Colombia, Guyana, Panama, Venezuela.

T. conspicua Melichar, 1926*. Ecuador.

T. costalimai Young, 1968. Brazil, Guyana, Venezuela.

T. cribrata Melichar, 1926. Argentina, Bolivia, Brazil, French Guiana, Peru.

T. dentalis Emmrich, 1988. Argentina, Brazil (new record), Paraguay.

T. diminuta sp. nov. Brazil.

T. elegantula sp. nov. Brazil.

T. lateritia (Taschenberg, 1884)* Brazil.

T. notatifrons Melichar, 1926. Argentina, Bolivia, Brazil, Ecuador, French Guiana, Paraguay, Suriname.

T. punctatissima Melichar, 1926. Colombia, Ecuador, Peru, Venezuela.

T. tomentosa (Distant, 1908). Ecuador. 
Tretogonia diminuta sp. nov. urn:1sid:zoobank.org:act:14DBD866-B599-4EBF-945B-5DD990BB4A7C

Figs 1-9

\section{Diagnosis}

Body short and robust (Figs 1-2) in comparison to other species of the genus; in dorsal view, head triangular (Fig. 1); pygofer with process serrated apically (Fig. 5); aedeagus with distinct dorsoapical lobe (Fig. 8).

\section{Etymology}

The specific epithet, 'diminuta', refers to the small body size, this being the smallest species of the genus.

\section{Material examined}

Holotype

BRAZIL • đ’; "S. [São] J. [José] [dos] PINHAIS PR [State of Paraná] / Brasil II-1982 / CAVICHIOLI Leg"; DZUP 215385.

\section{Type locality}

São José dos Pinhais, Paraná, South Brazil.

\section{Measurement}

Body length: holotype (ठ) $8.2 \mathrm{~mm}$.

\section{Description}

Male

Coloration. General coloration (Figs 1-3) brown. Frons and clypeus yellowish-brown; lorum darker and gena pale yellow. Pronotum with anterior and posterior margins dark brown. Scutellum pale yellow. Forewing with lighter area along costal margin from base to approximately level of apex of clavus; membrane area translucent. Foreleg mostly reddish-brown; middle and hind legs mostly pale brown with darker areas.

StRUCTURE. Head in dorsal view (Figs 1-3): well produced anteriorly, triangular, median length of crown slightly more than $1 / 2$ of interocular width and almost $3 / 10$ of transocular width; without carina at transition from crown to face; ocelli located slightly before imaginary line between anterior eye angles, each ocellus approximately equidistant between midline of crown and adjacent anterior eye angle; frontogenal suture extending onto crown and almost attaining ocellus; coronal suture distinct basally. Antennal ledge slightly protuberant; in lateral view (Fig. 2), distinctly bicarinate with surface between dorsal and ventral carinae depressed. Frons (Figs 2-3) convex with distinct muscle impressions; texture of central portion granular; epistomal suture obsolete medially; clypeus laterally with basal protuberance; apex rounded. Thorax (Figs 1-2) with pronotal width, between humeri, smaller than transocular width of head; pronotum elongate, attaining scutoscutellar suture; disk, except on anterior portion, with numerous large deep pits, without pubescence. Mesonotum with scutellum slightly transversely striate. Forewing (Figs 1-2) with texture of clavus and corium coriaceous and coarsely pitted; four apical cells, base of fourth more proximal than base of third. Hind wing with vein R $2+3$ incomplete. Hind leg with femoral setal formula $2+1+1$ or $2+1$; knee almost attaining posterior margin of lateral pronotal lobe; first tarsomere with many small setae on plantar surface. 
Terminalia. Pygofer (Fig. 4) moderately produced posteriorly; broadly rounded distally; with few macrosetae and dispersed microsetae; ventral margin (Fig. 5) with process near half-length, curving inwards and serrated apically. Subgenital plate (Fig. 6) not fused to its counterpart; triangular; with numerous dispersed microsetae and few macrosetae near apex; dorsal surface with small tooth at apical third; plate not extending as far posteriorly as pygofer apex. Style (Fig. 7) elongate, almost attaining tooth of plate; apophysis with apical portion extremely expanded and forming pair of lateral teeth.

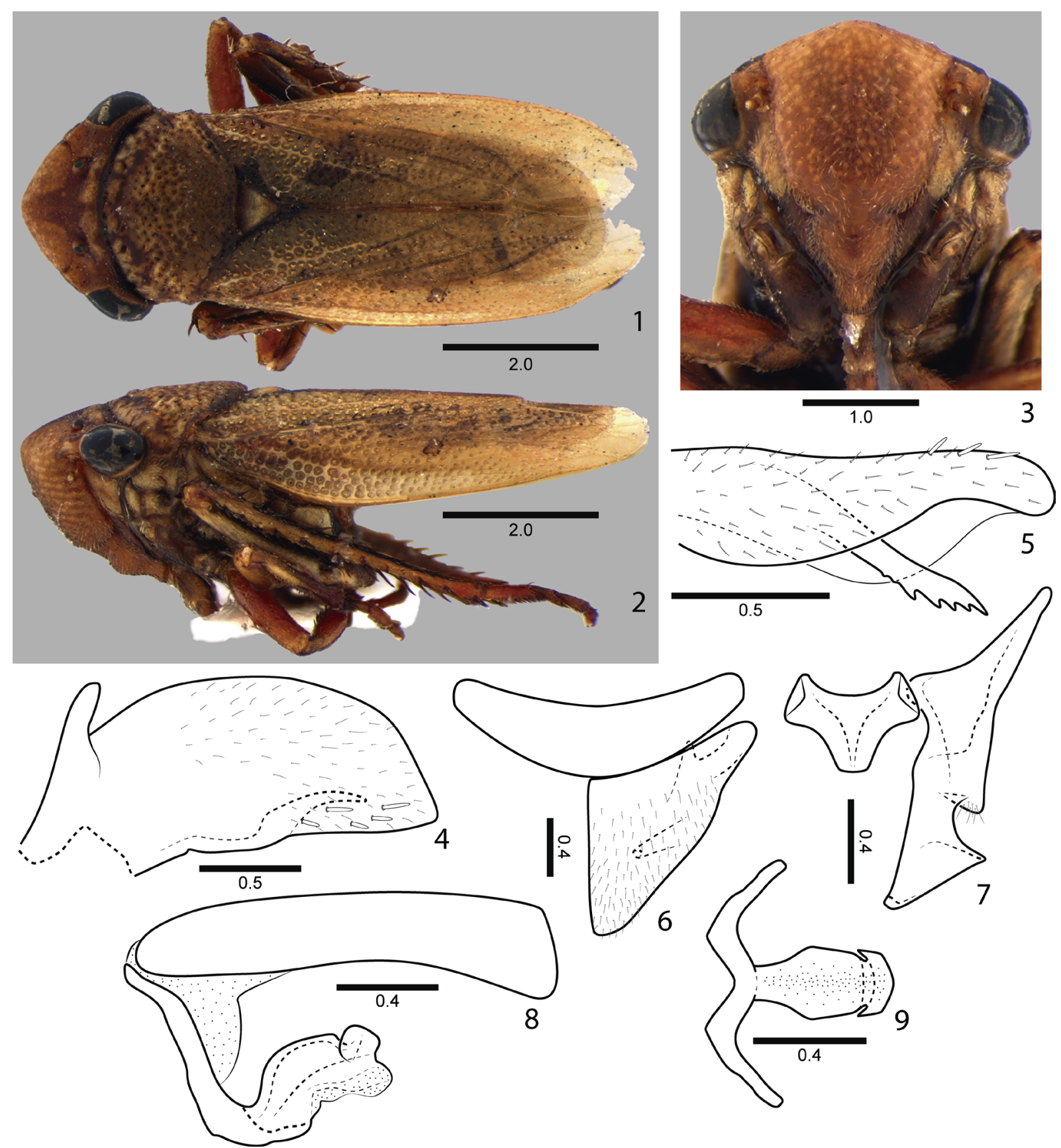

Figs 1-9. Tretogonia diminuta sp. nov., holotype, đ̊ (DZUP 215385). 1. Body, dorsal view. 2. Body, lateral view. 3. Face, frontal view. 4. Pygofer, lateral view. 5. Pygofer, dorsal view. 6. Valve and subgenital plate, ventral view. 7. Connective and style, dorsal view. 8. Aedeagus and basal segment of anal tube, lateral view. 9. Aedeagus, ventral view. Scales in $\mathrm{mm}$. 
Connective (Fig. 7) Y-shaped; very short; stalk without median dorsal keel. Aedeagus symmetrical; shaft (Fig. 8) short; curved basally upwards and then strongly curved posteriorad; dorsal margin notched near apex; apical margin emarginated, forming dorsal lobe; in ventral view (Fig. 9), shaft expanded on distal half, constricted preapically and with pair of preapical short acute processes directed anteriorad.

\section{Female}

Unknown.

\section{Remarks}

Tretogonia diminuta sp. nov. can be distinguished from the other species of the genus by the combination of features provided in the diagnosis. The triangular head is useful for distinguishing $T$. diminuta $\mathrm{sp}$. nov. from the three species of the genus that are only known from females (T. albicans, $T$. conspicua and T. lateritia). In Young's monograph, the new species keys to couplet six due to the absence of basal aedeagal processes (Young 1968). This couplet establishes the distinction between T. cinerea and three species positioned at couplets seven and eight (T. punctatissima, T. costalimai and T. tomentosa); in T. cinerea the aedeagus has a pair of minute processes located on the basal half of the shaft (Young 1968) instead of the preapical processes of T. diminuta, whereas in T. punctatissima, T. costalimai and T. tomentosa it has no processes (Young 1968).

Tretogonia elegantula sp. nov. urn:lsid:zoobank.org:act:095C1480-94C1-4F50-9D3A-D665A64CC627

Figs 10-25

\section{Diagnosis}

Dorsum brown with contrasting beige markings on posterior region of crown, anterior half of pronotum, scutellum and forewing (larger spot on basal portion of corium and smaller one at bases of outer and median anteapical cells) (Figs 10-11); style with apophysis forming large apical lobe (Fig. 16).

\section{Etymology}

The specific epithet, 'elegantula', refers to the peculiar, distinctive beige markings of the new species (Figs 10-11).

\section{Material examined}

Holotype

BRAZIL • đ; "Brasil, Paraná, Tibagi / P. [Parque] E. [Estadual] do Guartelá, 1000m / 24³3'47"S 50¹5'26"W / 23-24.II.2017 Sweep / A.C. Domahovski leg."; DZUP 215386.

\section{Paratypes}

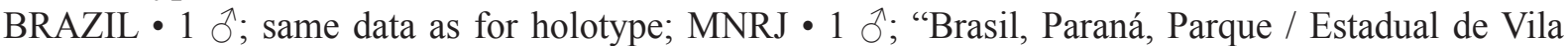
Velha / 2514'S 4559'W / 16.I.2004 G. Melo \& / R. Gonçalves"; MNRJ • 1 q; "BRASIL, Paraná, Parque / Estadual de Vila Velha / $25^{\circ} 13^{\prime} 5,0^{\prime \prime} \mathrm{S} 50^{\circ} 2^{\prime 2} 26,9^{\prime \prime} \mathrm{W} /$ Malaise 1 23.X.2000 / PROVIVE"; DZUP 215387.

\section{Type locality}

Tibagi (Parque Estadual do Guartelá), Paraná, South Brazil.

\section{Measurements}

Body length: holotype $\left({ }^{\Uparrow}\right) 9.6 \mathrm{~mm}$; male paratypes $9.6-9.8 \mathrm{~mm}(\mathrm{n}=2)$; female paratype $10.0 \mathrm{~mm}$. 


\section{Description}

\section{Male}

Coloration. General coloration (Figs 10-12) brown; body pits with white brochosomes. In dorsal view, head with dark brown to black stripe medially, extending from posterior to anterior margin, distinctly narrower basally and ovate from interocellar area to apex; posterior margin with two narrow beige
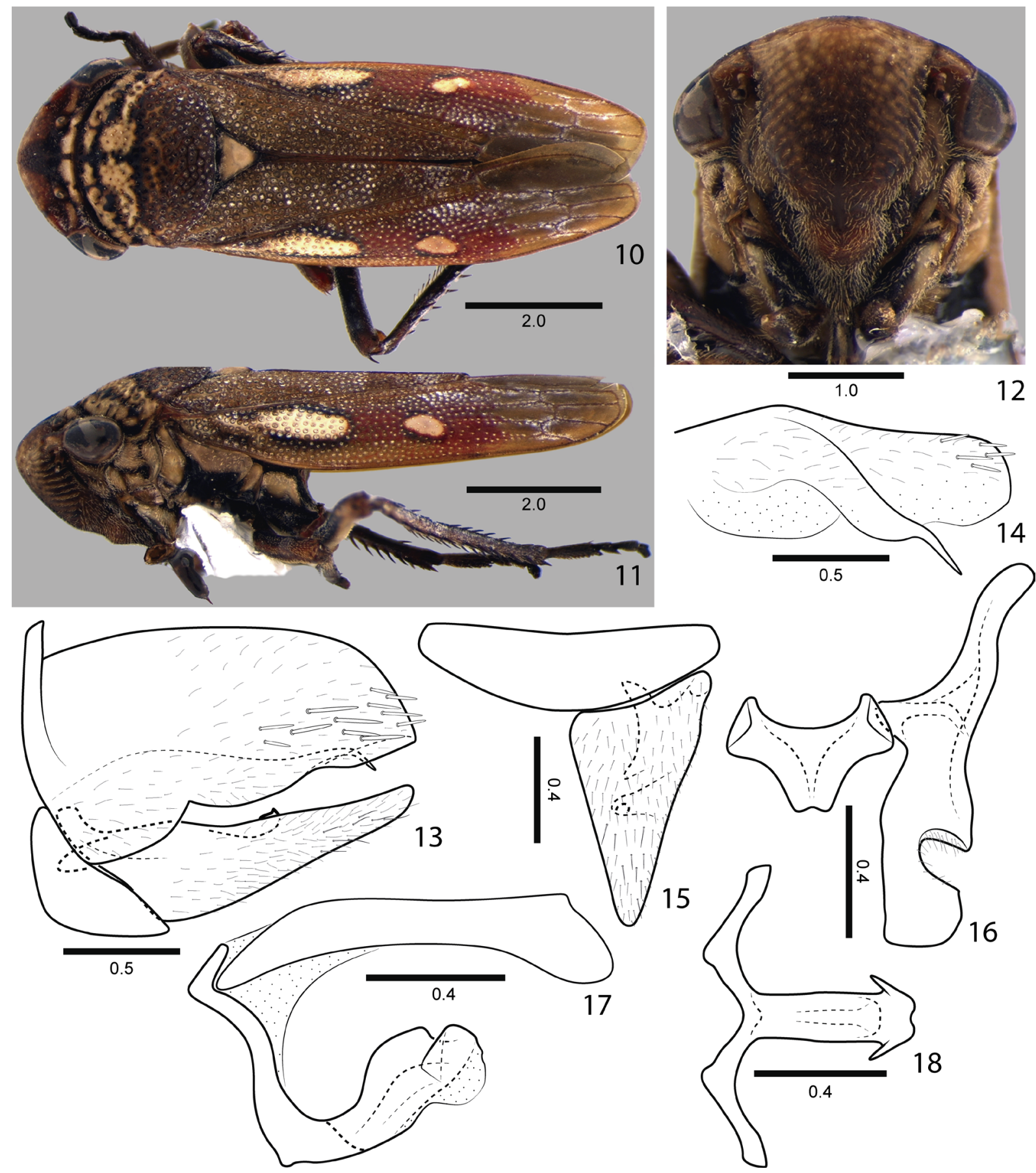

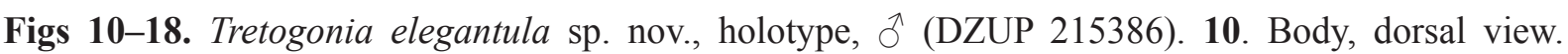
11. Body, lateral view. 12. Face, frontal view. 13. Valve, pygofer and subgenital plate, lateral view. 14. Pygofer, dorsal view. 15. Valve and subgenital plate, ventral view. 16. Connective and style, dorsal view. 17. Aedeagus and basal segment of anal tube, lateral view. 18. Aedeagus, ventral view. Scales in mm. 
maculae between coronal suture and inner eye margin, pair of narrow beige stripes between ocelli and inner eye margins. Pronotum with anterior margin narrowly black; anterior half of disk beige, with narrow, transverse irregular black stripe, median line with irregular narrow black stripe, posterior border of beige area black; posterior half of disk uniformly brown. Scutellum mostly beige. Lateral and ventral portions of thorax with small black markings on prothorax and much larger ones on mesoand metathorax, including hind coxa. Forewing with two beige rounded maculae, anterior one larger, margined with dark brown, located between $\mathrm{R}$ and claval sulcus; posterior one smaller, with incomplete dark brown margin, located at bases of outer and median anteapical cells; area between beige maculae and basal half of anteapical cells reddish-brown; costal area pale brown; membrane (distal half of anteapical cells and apical cells) pale brown and translucid. Legs with brown, dark brown to black, and beige tonalities; posterior femur with contrasting dark brown and beige areas.

StRUCTURE. Head in dorsal view (Figs 10-12): well produced anteriorly, triangular, median length of crown almost $1 / 2$ of interocular width and almost $3 / 10$ of transocular width. Other features of head and thorax much as in T. diminuta sp. nov. and in the description of the genus by Young (1968: 166).

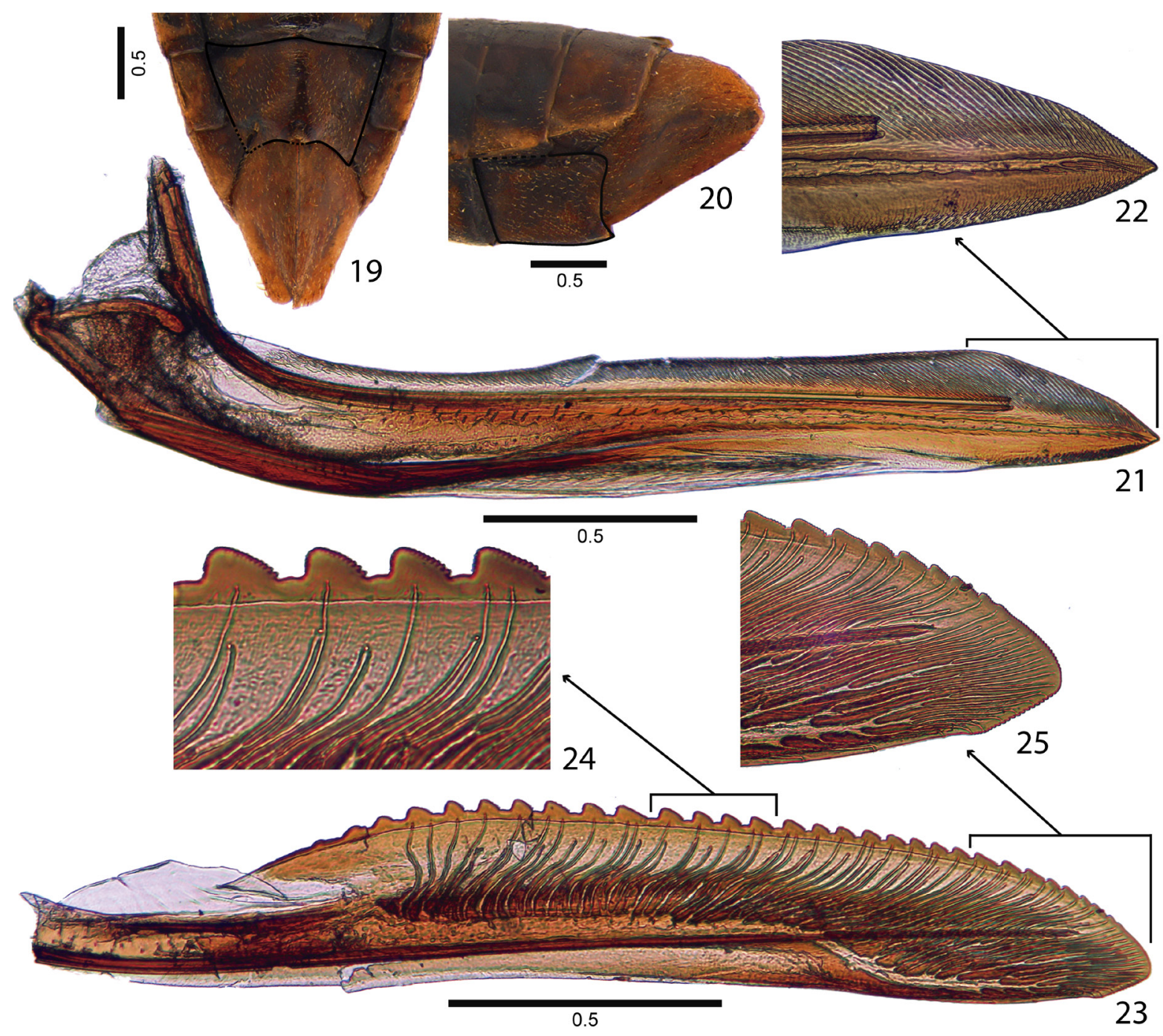

Figs 19-25. Tretogonia elegantula sp. nov., paratype, ( (DZUP 215387). 19-20. Distal portion of abdomen (contour of sternite VII highlighted). 19. Ventral view. 20. Lateral view. 21-22. First valvula. 21. General lateral view. 22. Detail of apical portion. 23-25. Second valvula. 23. General lateral view. 24. Detail of median portion. 25. Detail of apical portion. Scales in $\mathrm{mm}$. 
Terminalia. Pygofer (Fig. 13) moderately produced posteriorly; broadly rounded distally, angulate at apex; with dispersed microsetae and ventroapically with macrosetae; ventral margin with elongate sinuous process originated from basal third, reaching apical margin, apex acute. Subgenital plate (Fig. 15) not fused to its counterpart; triangular; with numerous dispersed microsetae and few macrosetae near apex; dorsal surface with small tooth at median third; plate (Fig. 13) extending as far posteriorly as pygofer apex. Style (Fig. 16) elongate, attaining tooth of plate; extremely expanded apically, forming conspicuous lobe. Connective (Fig. 16) Y-shaped; very short; stalk without median dorsal keel. Aedeagus symmetrical; shaft (Fig. 17) short, straight, without lateral expansions, with dorsal preapical hump; apical region expanded; in ventral view (Fig. 18), shaft somewhat anchor-shaped apically, with pair of preapical short acute processes directed anteriorad.

\section{Female}

Externally similar to male but slightly larger $(10.0 \mathrm{~mm})$.

Terminalia. Sternite VII (Fig. 19) with posterior margin shallowly emarginate, with slight median lobe. Pygofer (Fig. 20) slightly produced posteriorly; posterior margin rounded; surface with small macrosetae mostly near posterior margin and along ventral margin, with scattered microsetae. First valvula (Fig. 21) with dorsal and ventral margins approximately parallel for most of their length beyond basal curvature; apex acute; dorsal sculptured area (Fig. 22) extending from basal portion to apex of blade, strigate; ventral sculptured area (Fig. 22) restricted to apical portion of blade, formed mostly by scale-like processes; ventral interlocking device distinct on basiventral third of blade; in ventral view, basal portion of first valvula not modified or expanded. Second valvula (Fig. 23) expanded beyond basal curvature; preapical prominence inconspicuous; apex obtuse; dorsal margin convex, with about 30 mostly subtriangular teeth; denticles (Figs 24-25) distributed on teeth and on apical portion of blade, except on apex (ventral dentate apical portion slightly longer than dorsal one); blade with ducts extending towards teeth and apical portion (basalmost three teeth without associated ducts). Gonoplac of the usual Cicadellinae type (narrow basally and distinctly expanded apically; apex obtuse; surface with denticuli on apex and extending anteriorly along ventral margin).

\section{Remarks}

This new species can be readily distinguished from other members of the genus by the combination of features given in the diagnosis. The large forewing beige spots will distinguish $T$. elegantula sp. nov. from the three species of the genus that are known only from females (T. albicans, T. conspicua and T. lateritia). The forewings of T. conspicua have pale spots (see digital images in Wilson et al. 2009), but they are much smaller than those of the new species. As in the case of T. diminuta sp. nov., T. elegantula sp. nov. also keys to couplet six in Young's monograph due to the absence of basal aedeagal processes (Young 1968); the same comparative notes provided for $T$. diminuta sp. nov. apply here because the two new species share the presence of preapical aedeagal processes.

Tretogonia dentalis Emmrich, 1988

Figs 26-34

Tretogonia dentalis Emmrich, 1988: 189.

\section{Diagnosis}

Forewing with longitudinal broad beige band extending along costal margin from base to level of claval apex (Fig. 27); pygofer process with distal half directed dorsally (Fig. 29), serrated apically (Fig. 30); style with apophysis moderately expanded apically (Fig. 32); aedeagus with dorsal lobe followed by pair of dentiform processes directed anteriorad (Fig. 33). 


\section{Material examined}

BRAZIL • 1 ふे; "BRASIL, MS [State of Mato Grosso do Sul], Porto Murtinho, / Faz. Progresso

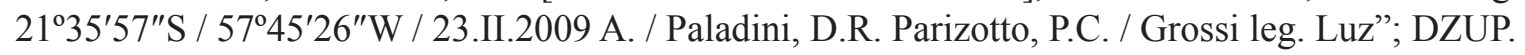

\section{Type locality}

San Bernardino, Paraguay (Emmrich 1988).

\section{Measurement}

Body length: $\lesssim 10.2 \mathrm{~mm}$.

\section{Description}

\section{Male}

Coloration. General coloration (Figs 26-28) brown. In dorsal view, head with small darker spots near posterior margin. Face light brown. Pronotum with dark brown, irregular Y-shaped marking on anterior half, its arms reaching humeri. Forewing with longitudinal broad beige band extending along costal margin from base to level of claval apex; inner border of this band with dark brown line; area between dark brown line and brachial cell reddish-brown; area of apical cells and distal part of anteapical cells light brown. Legs mostly brown to reddish-brown.

STRUCTURE. Head in dorsal view (Figs 26-28): moderately produced anteriorly, anterior margin rounded, median length of crown slightly more than $4 / 10$ of interocular width and almost $3 / 10$ of transocular width. Other features of head and thorax much as in T. diminuta sp. nov. and in the description of the genus by Young (1968: 166).

Terminalia. Pygofer (Fig. 29) moderately produced posteriorly, broadly rounded distally, angulate at apex; with dispersed microsetae and ventroapically with macrosetae; ventral margin with elongate process originated from basal third, its distal half directed dorsally, serrated apically (Fig. 30). Subgenital plate (Fig. 31) not fused to its counterpart; triangular, with small lobe on basal half of outer margin; with numerous dispersed microsetae and few macrosetae near apex; dorsal surface with small tooth at median third; plate (Fig. 29) not extending as far posteriorly as pygofer apex. Style (Fig. 32) elongate, attaining tooth of plate; apophysis moderately expanded and obtuse apically. Connective (Fig. 32) Y-shaped; very short; stalk without median dorsal keel. Aedeagus symmetrical; shaft (Fig. 33) short, straight, without lateral expansions; with dorsal lobe followed by pair of dentiform processes; in ventral view (Fig. 34), shaft somewhat anchor-shaped apically, with afore-mentioned pair of preapical dentiform processes directed anteriorad.

\section{Remarks}

Our identification of $T$. dentalis is based on a comparison of our male specimen from the State of Mato Grosso do Sul with the original description and illustrations by Emmrich (1988). This is the first record of $T$. dentalis from Brazil. This species, described based on a single male from Paraguay and also recorded from Argentina (Dellapé 2016), can be recognized by the combination of features provided in the diagnosis. Our comparative studies on species of Tretogonia suggest that $T$. dentalis could be a junior synonym of T. lateritia (Taschenberg, 1884). The color pattern of the female holotype of the latter species, described from "Paraná" and deposited at the Martin-Luther-Universität (Halle-Wittenberg, Germany), is quite similar to that of our male specimen (see digital image of the holotype in Wilson et al. 2009). However, we refrain from proposing a new synonym at this time because the taxonomy of Tretogonia is currently based mainly on features of the male terminalia (see Young 1968). Also, we do not have at hand a female specimen for comparison with the holotype of T. lateritia. 


\section{Discussion}

With the addition of $T$. diminuta sp. nov. and $T$. elegantula sp. nov., Tretogonia now comprises 15 Neotropical species, being a moderately diverse genus within the Proconiini; the largest genus of the tribe, with 61 species, is Oncometopia Stål, 1869 (see Rakitov 2016.) Accurate identification of some of the species of Tretogonia is not always easy because subtle details of the male terminalia must be considered. For instance, minor differences in the apical portion of the style apophysis currently form the basis for recognizing T. callifera, T. cribrata and T. notatifrons, three species widely distributed in South America (Young 1968). Thus, it is possible that new synonyms, in addition to that suggested above for T. dentalis, will have to be proposed in the future.

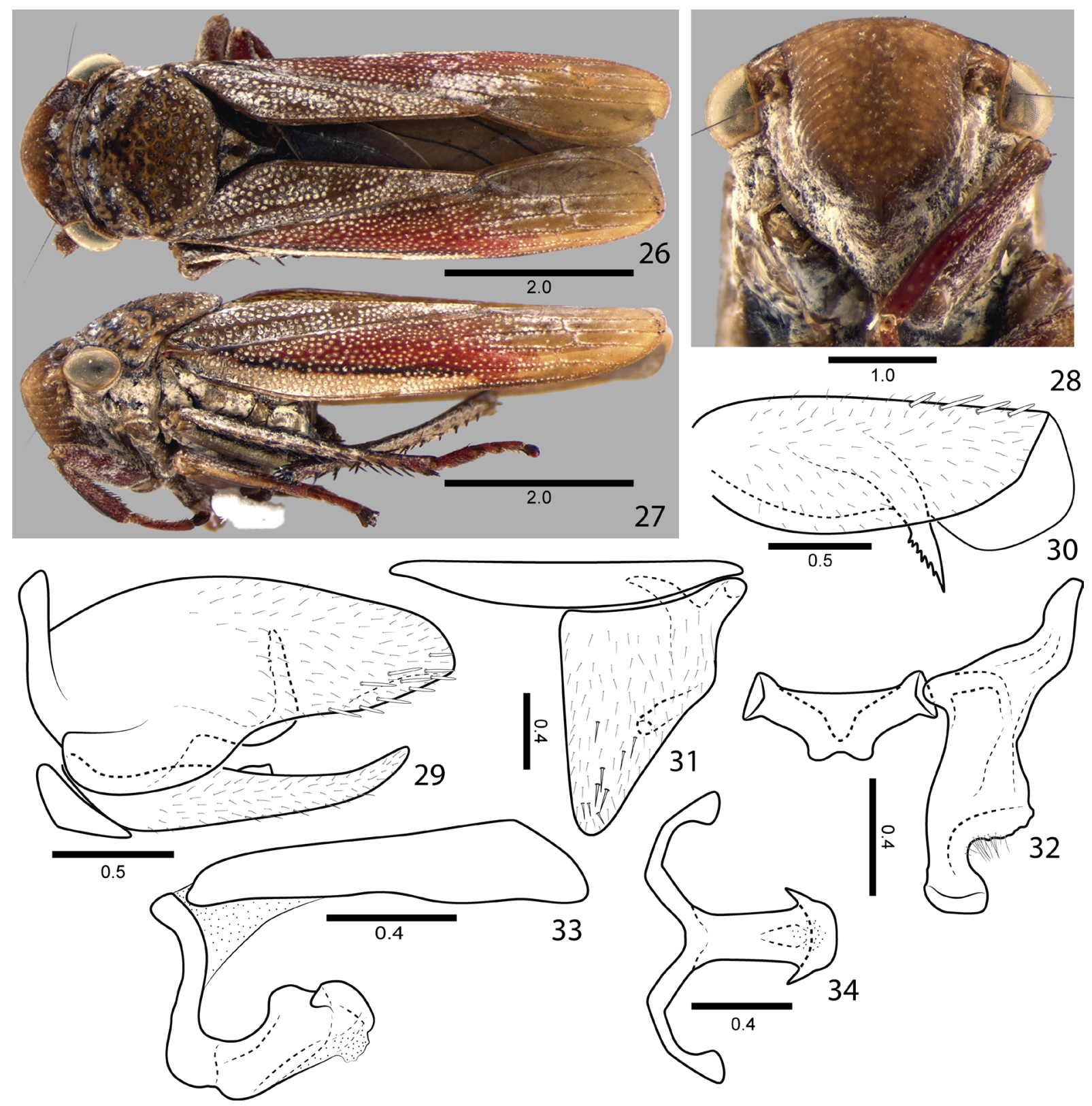

Figs 26-34. Tretogonia dentalis Emmrich, 1988, ô (DZUP 215388). 26. Body, dorsal view. 27. Body, lateral view. 28. Face, frontal view. 29. Valve, pygofer and subgenital plate, lateral view. 30. Pygofer, dorsal view. 31. Valve and subgenital plate, ventral view. 32. Connective and style, dorsal view. 33. Aedeagus and basal segment of anal tube, lateral view. 34. Aedeagus, ventral view. Scales in mm. 
This study, along with other recent publications on the taxonomy of Proconiini (e.g., Takiya \& Mejdalani 2011; Mejdalani et al. 2012; Rakitov 2016; Silva et al. 2017; Pinto et al. 2017), shows that the fauna of this tribe in the Neotropical region is still poorly known, perhaps especially so in the Amazon forest. Additional studies carried out in megadiverse countries, such as Brazil and Peru, will certainly uncover many more new species and, perhaps, a few new genera from this interesting leafhopper tribe. Our studies on Tretogonia will continue with a morphological phylogenetic analysis of the genus.

\section{Acknowledgements}

This work was supported by Conselho Nacional de Desenvolvimento Científico e Tecnológico (CNPq) stipends to ACD and DIR-M (processes 140815/2017-1 and 131294/2017-2, respectively). RRC and GM are research productivity fellows of CNPq (processes 305484/2014-1 and 303627/2014-0, respectively). The manuscript benefited from the useful comments of Dr. James Zahniser, one anonymous reviewer and section editor Dr. Anna Namyatova. This paper is contribution number 1967 of the Departamento de Zoologia, Universidade Federal do Paraná (UFPR).

\section{References}

Carvalho R.A. \& Mejdalani G. 2006. Two new species of the sharpshooter genus Desamera from northern Brazil (Insecta: Hemiptera: Cicadellidae). Zootaxa 1109: 15-26.

Cavichioli R.R. \& Takiya D.M. 2012. Description of a new species of Wolfniana and new records of Rotigonalia (Hemiptera: Cicadellidae: Cicadellinae) from the state of Amazonas, Brazil. Zoologia 29: 85-88. https://doi.org/10.1590/S1984-46702012000100011

Cavichioli R.R. \& Zanol K.M.R. 1991. Espécies de Cicadellinae, Deltocephalinae (Homoptera, Cicadellidae) da Ilha de Maracá, Roraima. Acta Amazonica 21: 55-61.

https://doi.org/10.1590/1809-43921991211061

Dellapé G. 2016. Description of the female terminalia of twelve species of Proconiini and a key to genera from Argentina (Insecta: Hemiptera: Cicadellidae). Zootaxa 4117: 211-225.

https://doi.org/10.11646/zootaxa.4117.2.5

Emmrich R. 1988. Eine neue Art der Gattung Tretogonia MEL. aus Paraguay (Insecta, Homoptera, Auchenorrhyncha, Cicadellidae). Reichenbachia 25: 189-190.

Evans J.W. 1947. A natural classification of leaf-hoppers (Jassoidea, Homoptera). Part 3: Jassidae. Transactions of the Royal Entomological Society of London 98: 105-271.

https://doi.org/10.1111/j.1365-2311.1947.tb01054.x

Freytag P.H. \& Sharkey M.J. 2002. A preliminary list of the leafhoppers (Homoptera: Cicadellidae) of Colombia. Biota Colombiana 3: 235-283.

Hamilton K.G.A. 1981. Morphology and evolution of the rhynchotan head (Insecta: Hemiptera, Homoptera). Canadian Entomologist 113: 953-974. https://doi.org/10.4039/Ent113953-11

Hill B.G. 1970. Comparative Morphological Study of Selected Higher Categories of Leafhoppers (Homoptera: Cicadellidae). PhD Thesis, North Carolina State University, Raleigh, USA.

McKamey S.H. 2007. Taxonomic catalogue of the leafhoppers (Membracoidea). Part 1. Cicadellinae. Memoirs of the American Entomological Institute 78: 1-394.

Mejdalani G. 1993. Morfologia da cabeça de Versigonalia ruficauda (Walker, 1851), com notas sobre a terminologia (Homoptera, Cicadellidae, Cicadellinae). Revista Brasileira de Entomologia 37: 279-288. 
Mejdalani G. 1998. Morfologia externa dos Cicadellinae (Homoptera, Cicadellidae): comparação entre Versigonalia ruficauda (Walker) (Cicadellini) e Tretogonia cribrata Melichar (Proconiini), com notas sobre outras espécies e análise da terminologia. Revista Brasileira de Zoologia 15: 451-544. https://doi.org/10.1590/S0101-81751998000200015

Mejdalani G. 2000. Morfologia Externa e Análise Cladística dos Gêneros de Proconiini com o Mero Posterior Exposto (Hemiptera, Cicadellidae, Cicadellinae). DSc Thesis, Universidade de São Paulo, São Paulo, Brazil.

Mejdalani G. \& Emmrich R. 1998. Notes on Neotropical Proconiini: new species of Acrobelus Stål and Dichrophleps Stål and the male of Proconosama haenschi (Melichar) (Auchenorrhyncha: Cicadellidae: Cicadellinae). Entomologische Abhandlungen - Staatliches Museum für Tierkunde Dresden 58: 131140 .

Mejdalani G., Cavichioli R.R. \& Carvalho R.A. 2012. Proconosama takiyae, a new sharpshooter from Ecuador, the female of $P$. alalia (Distant), and a key to the species of the genus (Hemiptera: Cicadellidae: Cicadellinae: Proconiini). Zootaxa 3525: 75-82.

Melichar L. 1926. Monographie der Cicadellinen. III. Annales Historico-Naturales Musei Nationalis Hungarici 23: 273-394.

MetcalfZ.P. 1965. General Catalogue of the Homoptera. Fascicle VI. Cicadelloidea. Part 1. Tettigellidae. United States Department of Agriculture, Agricultural Research Service, Washington DC.

Nielson M.W. 1965. A revision of the genus Cuerna (Homoptera, Cicadellidae). Technical Bulletin of the United States Department of Agriculture 1318: 1-48.

Nielson M.W. \& Knight W.J. 2000. Distributional patterns and possible origin of leafhoppers (Homoptera, Cicadellidae). Revista Brasileira de Zoologia 17: 81-156.

https://doi.org/10.1590/S0101-81752000000100010

Oman P.W. 1949. The Nearctic leafhoppers (Homoptera: Cicadellidae). A generic classification and check list. Memoirs of the Entomological Society of Washington 3: 1-253.

Pinto A.P., Mejdalani G. \& Takiya D.M. 2017. Unraveling the white-clothed Diestostemma Amyot \& Serville: a taxonomic revision of the American sharpshooters of the D. bituberculatum complex (Hemiptera: Cicadellidae). Zootaxa 4281: 135-164. https://doi.org/10.11646/zootaxa.4281.1

Rakitov R.A. 2016. The Oncometopia orbona species group (Hemiptera, Cicadellidae, Proconiini). Zootaxa 4168: 109-133. https://doi.org/10.11646/zootaxa.4168.1.5

Redak R.A., Purcell A.H., Lopes J.R.S., Blua M.J., Mizell III R.F. \& Andersen P.C. 2004. The biology of xylem fluid-feeding insect vectors of Xylella fastidiosa and their relation to disease epidemiology. Annual Review of Entomology 49: 243-270. https://doi.org/10.1146/annurev.ento.49.061802.123403

Silva R.S., Cavichioli R.R., Takiya D.M. \& Mejdalani G. 2017. Descriptions of eight new Acrogonia species from the Amazon region, including peculiar features of the female genitalia (Hemiptera: Cicadellidae: Cicadellinae: Proconiini). Zootaxa 4244: 515-534.

https://doi.org/10.11646/zootaxa.4244.4.4

Takiya D.M. \& Mejdalani G. 2011. Review of the sharpshooter genus Splonia, with descriptions of three new submacropterous species (Hemiptera: Cicadellidae: Cicadellinae: Proconiini). Annals of the Entomological Society of America 104: 141-148. https://doi.org/10.1603/AN10155

Takiya D.M., Cavichioli R.R., Mejdalani G., Felix M., Gonçalves C.C., Camisão B.M. \& Barbosa J.F. 2018. Cicadellidae in 'Catálogo taxonômico da fauna do Brasil'. PNUD. Available from http://fauna.jbrj.gov.br/fauna/faunadobrasil/11013 [accessed 20 Aug. 2018]. 
Wilson M.R., Turner J.A. \& McKamey S.H. 2009. Sharpshooter leafhoppers of the World (Hemiptera: Cicadellidae subfamily Cicadellinae). National Museum Wales. Available from http://naturalhistory.museumwales.ac.uk/Sharpshooters [accessed 20 Aug. 2018].

Young D.A. 1968. Taxonomic study of the Cicadellinae (Homoptera: Cicadellidae), Part 1, Proconiini. Bulletin of the United States National Museum 261: 1-287. https://doi.org/10.5962/bhl.part.20869

Young D.A. 1977. Taxonomic study of the Cicadellinae (Homoptera: Cicadellidae). Part 2. New World Cicadellini and the genus Cicadella. Bulletin of the North Carolina Agricultural Experiment Station 239: $1-1135$.

Manuscript received: 16 November 2018

Manuscript accepted: 7 March 2019

Published on: 9 April 2019

Topic editor: Gavin Broad

Section editor: Anna Namyatova

Desk editor: Danny Eibye-Jacobsen

Printed versions of all papers are also deposited in the libraries of the institutes that are members of the EJT consortium: Muséum national d'Histoire naturelle, Paris, France; Meise Botanic Garden, Belgium; Royal Museum for Central Africa, Tervuren, Belgium; Royal Belgian Institute of Natural Sciences, Brussels, Belgium; Natural History Museum of Denmark, Copenhagen, Denmark; Naturalis Biodiversity Center, Leiden, the Netherlands; Museo Nacional de Ciencias Naturales-CSIC, Madrid, Spain; Real Jardín Botánico de Madrid CSIC, Spain; Zoological Research Museum Alexander Koenig, Bonn, Germany. 